\title{
Plummer-Vinson Syndrome: A Rare Entity in Sub-Saharan Africa
}

\author{
Ngalessami-Mouakosso Marlyse ${ }^{1}$, Itoua-Ngaporo Ngala Akoa ${ }^{1,2}$, Ahoui-Apendi Clausina ${ }^{1,2}$, \\ Mongo-Onkouo Arnaud 1,2*, Mimiesse-Monamou Jile Florient1,2, Rody Stéphane Ngami1, \\ Deby-Gassaye ${ }^{1,2}$, Atipo Ibara Blaise Irénée ${ }^{1,2}$, Ibara Jean-Rosaire ${ }^{1,2}$ \\ ${ }^{1}$ Department of Gastroenterology and Internal Medicine, University Hospital of Brazzaville, Brazzaville, Congo \\ ${ }^{2}$ Faculty of Health Sciences of Marien Ngouabi University of Brazzaville, Brazzaville, Congo \\ Email: *mongoonkouo@gmail.com
}

How to cite this paper: Marlyse, N.-M., Akoa, I.N.N., Clausina, A.A., Arnaud, M.-O., Florient, M.M.J., Ngami, R.S., Gassaye, D., Irénée, A.I.B. and Jean-Rosaire, I. (2019) Plummer-Vinson Syndrome: A Rare Entity in Sub-Saharan Africa. Open Journal of Gastroenterology, 9, 109-112.

https://doi.org/10.4236/ojgas.2019.96013

Received: May 9, 2019

Accepted: June 24, 2019

Published: June 27, 2019

Copyright $\odot 2019$ by author(s) and Scientific Research Publishing Inc. This work is licensed under the Creative Commons Attribution International License (CC BY 4.0).

http://creativecommons.org/licenses/by/4.0/

\begin{abstract}
Plummer-Vinson syndrome (PVS) is a rare condition characterized by classical triad; high dysphagia, iron-deficiency anemia and oesophageal ring formation. We report a case of PVS in a 62-year-old patient admitted to the department of gastroenterology and internal medicine for high dysphagia. The clinical examination showed anemic syndrome, general impairment and polyarthritis. Biological examinations concluded to iron deficiency anemia. The endoscopy had observed a circular ring immediately above Killian's mouth ruptured during the examination. The patient was treated with iron and proton pump inhibitors. The oesophageal symptomatology regressed completely from the second day of treatment.
\end{abstract}

\section{Keywords}

Plummer Vinson, Dysphagia, Iron Deficiency Anemia, Oesophagealring, Africa

\section{Introduction}

Plummer Vinson syndrome (PVS) or Kelly Patterson's syndrome was firstly described by Kelly and Patterson in 1919 and then 3 years later by Plummer and Vinson. It is a rare disease characterized by high dysphagia associated with iron deficiency anemia and oesophageal ring formation [1].

Most of the patients are Caucasian women between 40 and 80 years old.

The global prevalence is poorly evaluated, but this syndrome is more and more described in Sub-Saharan Africa [2] [3] [4] [5].

We report a case of PVS diagnosed in the department of gastroenterology and 
internal medicine of the Hospital and University Center of Brazzaville.

\section{Observation}

Mrs. N., born in 1945, consulted on January 4, 2019, for high progressive dysphagia for about 5 months. Dysphagia was associated with hypersialorrhea et progressive weight loss.

She had no chest pain, regurgitation, hiccups or hematemesis. She has a history of hypertension for 5 years, treated by Amlodipine $10 \mathrm{mg}$ daily, and followed for an undetermined inflammatory polyarthritis with digital deformity since 1989, treated by Prednisolone $40 \mathrm{mg}$ daily. No history of smoking or alcohol drinking.

On clinical examination in Table 1, the hemodynamic parameters were stable, with blood pressure at $130 / 80 \mathrm{mmHg}$. His general condition was altered with conjunctival pallor, weight loss (current weight, $50 \mathrm{~kg}$, for a height of $1.62 \mathrm{~m}$ ) and WHO performance status at 3. Physical examination revealed a tumefaction at both elbows and wrists, with inflammatory characteristics. There was not palpable abdominal mass and cardiorespiratory examination was normal.

Upper gastrointestinal endoscopy showed a whitish circular ring $20 \mathrm{~cm}$ from the dental arches, broken after the passage of the endoscope, giving way to irregular and confluent ulcerations of the upper third of the esophagus. The endoscopic images were not made because the reprographer is down. Oesophageal baryta transit was normal as well as colonoscopy. The association of high dysphagia, iron deficiency anemia and an oesophageal ring evoked Plummer Vinson syndrome (PVS).

Iron supplementation has been introduced with ferrous sulfate at a dose of $200 \mathrm{mg}$ for 3 months. The ring was broken during endoscopy. The evolution was characterized by the resumption of the food from the 3rd day, a progressive recovery of the weight and a cicatrisation of the oesophageal ulcerations at the endoscopic control to one month. On a biological level, the control hemogram showed a hemoglobin count of $10.9 \mathrm{~g} / \mathrm{l}$. Ferritin increased from $13 \mu \mathrm{g}$ to $86 \mu \mathrm{g}$.

\section{Discussion}

Precise data on the prevalence of Plummer Vinson syndrome are not well known. It seemed common in the first half of the 20th century in the North, but today it has become extremely rare [1].

Table 1. The results of biological examinations are represented in the table below.

\begin{tabular}{cc}
\hline Exams & Setting \\
\hline hemoglobin & $9.6 \mathrm{gl}$ \\
Mean corpuscular volume & $79 \mathrm{fl}$ \\
Corpuscular hemoglobin concentration & $32.2 \mathrm{pg}$ \\
ferritin & $13 \mu \mathrm{g}$ \\
Serum iron & $0.51 \mathrm{mgl}$ \\
\hline
\end{tabular}


This condition was rarely reported in African black literature until recently [2] [3] [4] [5]. This is paradoxical in view of the high frequency of iron deficiency and malnutrition in Africa. The PVS most often affects young, middle-aged women [3]. This is the case of our patient. However, this syndrome can occur in children or adolescents [6].

Dysphagia is the main symptom. It is usually painless and intermittent, limited to solids. In our patient, the dysphagia was permanent and global, probably related to the severity of the oesophageal ring. This dysphagia had a high cervical seat.

In the PVS, the mechanism of dysphagia and the formation of the membrane are still unclear. Although iron deficiency is not necessary for the formation of the ring, it would always precede dysphagia [7]. However, the membrane would not be pathognomonic of the PVS. It is not essential for the emergence of swallowing disorders but rather acts as a factor of mechanical aggravation [8].

The association between SPV and Goujerot-Sogrën syndrome has been described, suggesting a possible autoimmune origin of SPV [9]. This is the case of our patient who has an inflammatory polyarthritis.

Biologically, iron deficiency anemia is very common in patients, up to $80 \%$ of cases [8]. Hyposideremia without anemia can be found in some patients. Some authors associate SPV with sideropenia more than with anemia [7].

Endoscopy visualizes the ring as a thin, gray membrane, with or without a centered lumen. The radiological abnormalities are constant at the pharyngo-oesophageal baryta transit [8]. In the early stage, the membrane appears as an indentation detaching from the anterior surface of the esophagus. At a later stage, it appears as an annular narrowing revealing the existence of a diaphragm [9] [10]. In our case, it was high oesophageal ulcerations, caused by the break-in of the ring during endoscopy.

In most cases, iron supplementation leads to a regression of dysphagia prior to the biological normalization of anemia, despite the persistence of the oesophageal ring [10].

The short-term evolution is favorable under specific treatment. Recurrence is possible in case of new iron deficiency [5]. An obstructive ring is often the cause of treatment resistance requiring endoscopic rupture or dilation sessions for regressing dysphagia. The evolution was favorable in our case, after iron supplementation, with clinical improvement. Long-term evolution is characterized by an increased risk of post-cricoid cancer, highlighting the precancerous nature of the SPV. It is therefore recommended to monitor patients with SPV [11].

\section{Conclusion}

Plummer Vinson syndrome is still rarely described in Africa. The current practice of digestive endoscopy tends to increase its prevalence. The short-term evolution is generally favorable after iron supplementation, but in the long term, it is marked by the fear of a post-cancerous cancer. 


\section{Conflicts of Interest}

The authors declare no conflicts of interest regarding the publication of this paper.

\section{References}

[1] Novacek, G. (2006) Plummer-Vinson Syndrome. Orphanet Journal of Rare Diseases, 15, 36. https://doi.org/10.1186/1750-1172-1-36

[2] Soumana, S., Belembaogo, E., Bertoni, G., et al. (2000) Syndrome de Plummer-Vinson: A Propos d'un Cas. Médecine d'Afrique Noire, 47, 218-220.

[3] Dia, D., Diouf, M.L., Mbengue, M., et al. (2010) Le syndrome de Plummer-Vinson: Aspects cliniques, paracliniques et thérapeutiques à propos de 19 cas à Dakar. Médecine d' Afrique Noire, 57, 189-192.

[4] Diop, M.M., Leye, M.Y., Toure, P.S., et al. (2012) Syndrome de Plummer-Vinson de découverte fortuite au cours d'une maladie de Biermer, cas et revue de la littérature. Revue Internationale des Sciences Médicales, 14, 165-168.

[5] Fall, F., Gning, S.-B., N'diaye, A.-R., et al. (2011) Le Syndrome de Plummer-Vinson: Étude Retrospective de 50 Cases. Journal Africain d Hépato-Gastroentérologie, 5, 259-263. https://doi.org/10.1007/s12157-011-0340-9

[6] Dinler, G. (2009) Plummer-Vinson Syndrome in a 15-Year-Old Boy. The Turkish Journal of Pediatrics, 51, 384-386.

[7] Elwood, P.C., Jacobs, A., Pitmann, R.G., et al. (1964) Epidemiology of the Patterson Kelly Syndrome. The Lancet, 284, 716-720. https://doi.org/10.1016/S0140-6736(64)92541-3

[8] Ekberg, O. and Nylander, G. (1983) Webs and Web-Like Formation in the Pharynx and Cervical Esophagus. Diagnostic Imaging, 52, 10-18.

[9] Ouakaa-Achaou, A., Jebali, S., Elloumi, H., et al. (2011) Association d'un Syndrome de Goujerot-Sjögren et d'un Syndrome de Plummer Vinson. La Revue de Médecine Interne, 32, 21-22. https://doi.org/10.1016/j.revmed.2010.03.459

[10] Rania, H., Yosra, B., Asma, O.K., et al. (2010) Syndrome de Plummer Vinson. Tunisie Médicale, 88, 721-724.

[11] Jessner, W., Vogelsang, H., Puspok, A., et al. (2003) Plummer-Vinson Syndrome Associated with Celiac Disease and Complicated by Postcricoid Carcinoma of the Tongue. The American Journal of Gastroenterology, 98, 1208-1209. 